\title{
Successful Treatment of Bloody Milk Not Associated With Physiologic Udder Edema in Lactating Holstein Dairy Cows Using Intravenous Formalin Administration
}

\author{
Zuhair BANI ISMAIL \\ Department of Veterinary Clinical Sciences, Faculty of Veterinary Medicine, Jordan University of Science \\ and Technology, Irbid 22110 - Jordan \\ *Corresponding author: zuhair72@just.edu.jo
}

Bulletin UASVM Veterinary Medicine 73(1) / 2016,

Print ISSN 1843-5270; Electronic ISSN 1843-5378

DOI:10.15835/buasvmcn-vm: 11945

\begin{abstract}
This study was carried out to evaluate the safety and efficacy of intravenous injection of 500-ml of $0.37 \%$ formalin as a treatment of hemolactia not associated with physiologic udder edema in dairy cattle. Fifteen adult lactating Holstein dairy cows suffering from hemolactia in one or more quarters were used. Another 10 cows with hemolactaia were not treated and used as a control. Cows were subjected to a complete physical examination before administration and daily for 7 days thereafter. Hematology, serum biochemistry, and the coagulation times (prothrombin time, activated partial thromboplastin time and thrombin time) in addition to D-dimers, fibrinogen concentration and platelets counts were evaluated before injection and 1 week after the last injection. Cows were followed-up for 12 months after the end of treatment for long-term side effects. Approximately eighty-one percent $(81.25 \%)$ of affected quarters were cured in an average of 4 days in the formalin-treated cows while less than $50 \%$ of cows that were not treated cured in approximately 7 to 8 days. There were no clinical, hematological or serum biochemical abnormalities associated with the injection of the drug. Platelets numbers were significantly increased and the activated partial thromboplastin clotting times (APTT) was significantly decreased in treated cows at 1 week after the last injection. Results of this study prove safe and effective, yet widely available and cheap treatment for dairy cows affected with hemolactia. This treatment will prevent significant production losses due to discard of unfit for human consumption bloody milk.
\end{abstract}

Keywords: bloody milk, coagulation, formalin, hemolactia, mastitis

\section{INTRODUCTION}

Bloody milk or hemolactia in lactating dairy cattle is relatively common in both heifers and multiparous cows (George et al., 2008; Radostits et al., 2007). Although the condition occurs sporadically, in certain geographic locations an incidence rate of over $50 \%$ has been reported in some herds (George et al., 2008; Radostits et al., 2007). In heifers, the condition is more commonly associated with severe udder edema around parturition. In multiparous cows, the condition is usually due to self-inflected trauma, trauma due to other cows kicking the udder or awkward posture during recumbency (George et al., 2008; Radostits et al., 2007). Thrombocytopenia has been documented in some cases but the exact role of this condition has not been elucidated yet (George et al., 2008; Radostits et al., 2007). Although, severe bleeding to cause hemorrhagic shock is not common, treatment in prolonged cases is requested because of the loss of milk production. In cattle with hemolactia, intravenous 
administration of calcium borogluconate and some parenteral coagulants have been tried for the treatment of this condition but scientific evidence of their safety and efficacy is lacking (Ayaz, 1999; Eddy and Clark, 1982; Muhammad et al., 1997).

In horses, severe acute hemorrhage due to trauma, rupture of the uterine artery and epistaxis are considered life-threatening emergencies (Jones, 1998; Santschi, 1999; Taylor et al., 2000). Moreover, in human medicine, intractable hemorrhage from the urinary bladder and rectum associated with inflammatory, ulcerative or tumorous conditions present great challenges for the clinician (Choong et al., 2000; Lee et al., 2007; Manikandan et al., 2010). Topical and intralesional injection of formalin as a pro-coagulant has been tried treat intractable hemorrhage in dogs, horses and human beings with promising success (Choong et al., 2000; Henrikson et al., 2004; Kang et al., 2003; Lee et al., 2007; Mathai et al., 1995; Mohamed et al., 2012). However, the safety and efficacy of intravenous injection of formalin to dairy cattle affected with hemolactia was evaluated here for the first time. This may present a new and innovative, yet cheap treatment of this common condition.

\section{MATERIALS AND METHODS}

\section{Animals}

All procedures and protocols used in this study were approved by the animal care and use committee of Jordan University of Science and Technology (ACUC-JUST). The owner of the dairy farm from which animals were used in the study signed a written consent. The study was conducted using 15 adult lactating Holstein dairy cows from the same farm. The farm is located in Al-Dulail City in the Northern East of Jordan. The study was conducted during the summer of 2015 between the months of April and August. The weather in this part of Jordan is characterized by long and hot dry summers (May to October) and windy, cold winters. The average temperatures can vary between $-1 \mathrm{C}^{\circ}$ to $37 \mathrm{C}^{\circ}$ and the yearly average rainfall is typically less than $200 \mathrm{~mm}$. There are 500 lactating Holstein dairy cows in the farm housed freely in open sheds. The cows are fed 3 times per day a total mixed ration with ad lib of fresh water. The cows are milked 3 times per day in a double 32-cow herringbone-milking parlor. Cows were selected for the study based on a clinical diagnosis of bloody milk at any stage of lactation.
Clinical examination and sample collection

Only cows with hemolactia not associated with physiologic udder edema were selected for this study. Selected cows were subjected to a complete physical examination on the farm either by the principle investigator or by the farm veterinarian. From each cow, a whole blood sample was collected via coccygeal vein puncture. Collected blood was divided into 3 portions and placed in EDTA and Citrate- containing tubes and in plain tubes. Sterile milk samples were also collected and placed in sterile tubes for bacterial culture and sensitivity testing. To assess the effect of formalin intravenous injection on various parameters, blood and milk samples were retaken 7 days after the last injection. For comparison, whole blood samples were also collected from 10 normal cows in a similar stage of lactation.

\section{Drug preparation and injection}

Cows were grouped into formalin-treated $(\mathrm{n}=15)$ and non-formalin-treated $(\mathrm{n}=10)$ cows and used as control. In the formalin-treated cows, 500 milliliters of $0.37 \%$ formaldehyde solution were administered intravenously. Non formalin-treated cows were not administered any medication and were left to self-cure. To make the desired solution, a $5-\mathrm{ml}$ of $37 \%$ formaldehyde solution (Chemanol, Saudi Arabia) was added into 500-ml sterile saline. Formaldehyde was passed through a $0.2 \mu \mathrm{m}$ single use Ministart filter (Sigma, Germany) to make the solution ready for intravenous administration. Intravenous administration was then accomplished by injecting the drug via the jugular vein using IV catheter (Angiocath, 16GA X 5.25", Medline Industries, Illinois, USA) over 5 minutes period. Cows were administered the drug once a day until cure was achieved or for a maximum of 5 to 7 injections. Normal control cows were not administered any drugs.

\section{Adjunctive treatments}

Randomly selected cows in the formalintreated group were administered additionally 400 $\mathrm{ml}$ of calcium borogluconate 11.88g intravenously (Calciject 40, Norbrook, Northamptonshire, UK) and one dose of Vitamin K1 (Neogen Corporation, Lexington, Kentucky, USA) at $2.5 \mathrm{mg} / \mathrm{kg}$ intramuscularly as an adjunctive treatment on day 1 .

\section{Safety and behavioral effects}

The safety of the drug was evaluated by monitoring physical examination parameters; temperature, heart rate, respiratory rate, mucus 
membrane color, capillary refill time, rumen motility, and any abnormal behavior or activity of the cow like salivation, urination and defecation, tremors etc.. To assess the long-term effects, all cows were clinically examined and whole blood and milk samples were recollected again at 1 week after the last injection. Furthermore, the health status of all cows was followed-up for 12 months.

\section{Hematology and serum biochemical analyses}

The total white blood cell count (WBC), red blood cell count (RBC), hemoglobin concentration $(\mathrm{Hb})$, packed cell volume (PCV), mean corpuscular volume (MCV), mean corpuscular hemoglobin concentration (MCHC)and platelets count were determined using an electric cell counter (ABC Vet hematology analyzer, ABX Diagnostics, Maizy, France). Fibrinogen concentrations were determined using heat-precipitation method (Thrall, 2004).

Serum was obtained by centrifugation of clotted blood samples at 1500g for 10 minutes. Serum then was analyzed using routine methods including total protein, blood urea nitrogen, creatinine, aspartate aminotransferase (AST), alanine aminotransferase (ALT), alkaline phosphatase (ALP), calcium, sodium, chloride and potassium.

\section{Clotting factors determination}

Whole blood in Citrate-containing tubes was used to determine the following clotting parameters: activated partial thromboplastin time (APTT) (STA- C.K. Prest, Stago, France), prothrombin time (PT) (Néoplastine CI Plus, Stago France), thrombin time (TT) (STA -Thrombin, Stago, France), and D-Dimers (D-Di Test, Stago, France). Laboratory analyses were performed within 2 hours 3 hours of sample collection.

\section{Milk culture and antimicrobial sensitivity} testing

Individual milk samples from affected cows were obtained from each quarter aseptically, placed in sterile tubes, and sent for bacterial culture and antibacterial sensitivity testing using routine methods (Oliver et al., 2004).

\section{Statistical analysis}

Data was presented as mean \pm standard deviation. Repeated measure analysis of each of the evaluated variables was performed using GLM repeated measures. Post-hoc pairwise comparisons were performed using Bonferroni test. Differences were considered statistically significant if the $\mathrm{P} \leq 0.05$. The analysis was conducted using statistical software (SPSS, Version 19.0, SPSS Inc, Chicago, USA).

\section{RESULTS AND DISCUSSION \\ Animals and initial clinical examination findings}

There were 25 cows (60 quarters) presented to the sick pen on the farm for evaluation of bloody milk. Fifteen of those cows (32 quarters) were administered formalin while the rest were not treated and used as control. The average parity and days in milk (DIM) of the formalin-treated cows were 2.3, and 124 respectively (Tab. 1). There were eight open cows and seven pregnant cows in different stages of pregnancy (Tab. 1). In the non formalin-treated cows, the average parity and DIM were 3 and 150 respectively. Three cows were pregnant.

Physical examination of the affected cows revealed normal temperature, heart rate, respiratory rate, mucus membrane color, capillary refill time, and rumen motility. Examination of the udder revealed mild to moderate swelling of the affected quarter. In the formalin-treated cows, there were eight cows affected in only 1 quarter, two cows in 2 quarters and five cows in 4 quarters. In the non formalin-treated group, there were two cows affected in 1 quarter, two cows affected in 2 quarters, 2 cows affect in 3 quarters and four cows affected in 4 quarters. The color of milk secretion ranged from blood-tinged to frank blood that is dark red to chocolate-like (Fig. 1). Blood clots were not seen. There were no other abnormalities involving any other body system in any of the affected cows.

\section{Therapeutic efficacy}

Twenty-six out the 32 quarters (81.25\%) were cured completely after intravenous formalin injection (Tab. 2). The average days to complete cure in the treated cows was 4 days. Out of the 26 cured quarters, 20 belonged to cows that received only formalin while the remaining 6 quarters belonged to cows that received formalin in addition to calcium borogluconate and vitamin K1 as an adjunctive treatment. Staphylococcus aureus was isolated from milk samples of four cows, 3 of them were cured after the administration of formalin and adjunctive treatments and the fourth cow was cured after the administration of formalin only. None of these cows was administered local or 
systemic antibiotics. In the non treated-cows, out of 28 affected quarters, only 15 were self-cured in an average of 7 to 8 days. Five quarters were cured in 13 to 15 days and 8 quarters were not cured at all. Milk sample culture revealed no bacterial growth in any of the control cows.

\section{Safety and behavioral effects}

All cows appeared to tolerate multiple, once per day intravenous injection of $500-\mathrm{ml}$ of $0.37 \%$ formaldehyde solution. The rectal temperature, heart rate, respiration rate, mucus membrane color, capillary refill time and rumen motility patterns were not changed significantly (data not shown) during or immediately after injection. There were no abnormal clinical signs such as salivation, urination, defecation, tremors or any other nervous signs or abnormal behaviors. None of the pregnant cows aborted immediately or during the following 6-12 months of follow-up period.

\section{Hematology and serum biochemical analyses}

Hematology and serum biochemical analyses in Holstein dairy cows before and 1 week after the last intravenous administration of $500-\mathrm{ml}$ of $0.37 \%$ formaldehyde solution once per day for $2-7$ injections are presented in Tables 3 and 4. There were no statistically significant changes in any of the measured parameters.

\section{Clotting factors}

Tab. 5 shows the results of various clotting factors in control and treated cows before and

Tab. 1. Some epidemiological information of 15 Holstein dairy cows affected with hemolactia.

\begin{tabular}{cccc}
\hline Cow number & Parity & Days in milk (DIM) & Reproductive status \\
\hline 1 & 2 & 72 & Open \\
\hline 2 & 3 & 150 & 1 month pregnant \\
\hline 3 & 3 & 160 & Open \\
\hline 4 & 1 & 150 & 7 months pregnant \\
\hline 5 & 2 & 260 & 2 month pregnant \\
\hline 6 & 3 & 120 & 5 months pregnant \\
\hline 7 & 2 & 180 & 5 months pregnant \\
\hline 8 & 2 & 300 & 7 months pregnant \\
\hline 9 & 2 & 180 & Open \\
\hline 10 & 2 & 12 & Open \\
\hline 11 & 3 & 8 & Open \\
\hline 12 & 1 & 157 & Open \\
\hline 13 & 3 & 1 & Open \\
\hline 14 & 1 & 10 &
\end{tabular}
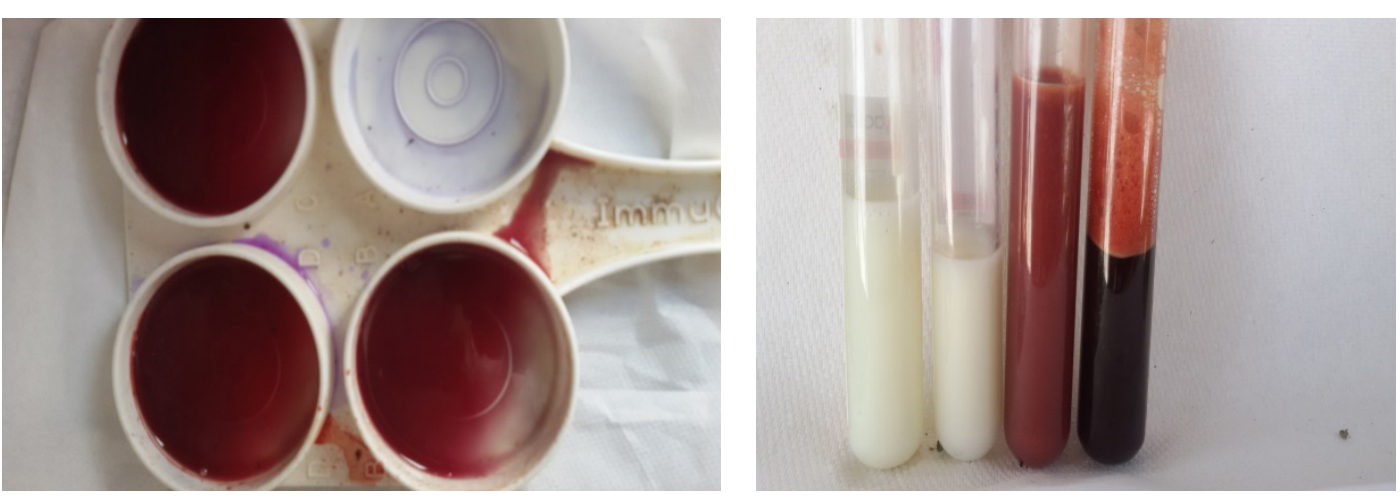

Fig. 1. Bloody milk secretion in a Holstein dairy cow treated with intravenous injection of $500-\mathrm{ml}$ of $0.37 \%$ formaldehyde solution. 
1 week after the intravenous administration of $500-\mathrm{ml}$ of $0.37 \%$ formaldehyde solution once per day for 2-7 injections. There were no significant differences in any of the parameters when it was compared between the normal cows and the values in treated cows before the administration of the drug. However, when comparisons were made in treated cows between those values before and 1 week after drug administration, a significant difference could be noticed in platelets numbers and APTT values. Platelets numbers were significantly increased in the post administration period, while the value of APPT was significantly decreased.

In this study, bloody milk was diagnosed in 25 cows (60 quarters), some of them were heifers while others were adult cows. All cows were in variable stages of lactation when the problem was diagnosed but none of them was fresh or suffering from physiologic udder edema. Therefore, the exact cause of the problem in this herd was difficult to ascertain. The fact that only 1 or 2 quarters were affected in most of the cows may indicate udder trauma may be considered as the cause of the problem.

Previous researchers have suggested that local or systemic infections such as mastitis or leptospirosis could be the cause of bloody milk in some herds (George et al., 2008; Radostits et al., 2007). Although, in this study, milk culture revealed Staphylococcus aureus in four cows, it was impossible to claim that this microorganism was the cause of bloody milk in those cows. It is interesting, however to notice that all cows from which Staphylococcus aureus was isolated completely, clinically and bacteriologically cured without the administration of either systemic or intramammary antibiotics. This could be

Tab. 2. Clinical and microbiological findings, treatment regimens and outcome of 15 Holstein dairy cows affected with hemolactia.

\begin{tabular}{|c|c|c|c|c|c|}
\hline $\begin{array}{l}\text { Cow } \\
\text { number }\end{array}$ & $\begin{array}{l}\text { Number of } \\
\text { quarters } \\
\text { affected }\end{array}$ & $\begin{array}{l}\text { Milk culture } \\
\text { results }\end{array}$ & $\begin{array}{c}\text { Number of } \\
\text { formalin doses } \\
\text { administered }\end{array}$ & Adjunctive treatments & $\begin{array}{l}\text { Treatment } \\
\text { outcome }\end{array}$ \\
\hline 1 & 1 & Negative & 3 & None & Cured \\
\hline 2 & 1 & Negative & 3 & $\begin{array}{c}\text { Calcium borogluconate 11.88g IV } \\
\text { once; Vitamin K1 2.5mg/kg IM once }\end{array}$ & Cured \\
\hline 3 & 2 & $\begin{array}{l}\text { Staphylococcus } \\
\text { aureus }\end{array}$ & 3 & $\begin{array}{c}\text { Calcium borogluconate } 11.88 \mathrm{~g} \text { IV } \\
\text { once; Vitamin K1 } 2.5 \mathrm{mg} / \mathrm{kg} \text { IM once }\end{array}$ & Cured \\
\hline 4 & 1 & $\begin{array}{l}\text { Staphylococcus } \\
\text { aureus }\end{array}$ & 3 & $\begin{array}{c}\text { Calcium borogluconate } 11.88 \mathrm{~g} \text { IV } \\
\text { once; Vitamin K1 2.5mg/kg IM once }\end{array}$ & Cured \\
\hline 5 & 1 & Negative & 3 & $\begin{array}{c}\text { Calcium borogluconate 11.88g IV } \\
\text { once; Vitamin K1 2.5mg/kg IM once }\end{array}$ & Cured \\
\hline 6 & 4 & Negative & 5 & None & Cured \\
\hline 7 & 2 & Negative & 5 & None & $\begin{array}{l}1 \text { quarter } \\
\text { not cured }\end{array}$ \\
\hline 8 & 1 & $\begin{array}{l}\text { Staphylococcus } \\
\text { aureus }\end{array}$ & 6 & $\begin{array}{l}\text { Calcium borogluconate 11.88g IV } \\
\text { once; Vitamin K1 2.5mg/kg IM once }\end{array}$ & Cured \\
\hline 9 & 4 & Negative & 2 & None & Cured \\
\hline 10 & 1 & Negative & 5 & None & Cured \\
\hline 11 & 1 & Negative & 5 & None & Cured \\
\hline 12 & 1 & Negative & 5 & None & Cured \\
\hline 13 & 4 & $\begin{array}{l}\text { Staphylococcus } \\
\text { aureus }\end{array}$ & 5 & None & Cured \\
\hline 14 & 4 & Negative & 5 & $\begin{array}{l}\text { Calcium borogluconate 11.88g IV } \\
\text { once; Vitamin K1 2.5mg/kg IM once }\end{array}$ & $\begin{array}{l}4 \text { quarters } \\
\text { not cured }\end{array}$ \\
\hline 15 & 4 & Negative & 7 & None & $\begin{array}{l}1 \text { quarter } \\
\text { not cured }\end{array}$ \\
\hline
\end{tabular}


explained by incidental isolation of the bacteria from intermittent shedders in cows with chronic subclinical infections.

Although, milk samples were not cultured for Leptospira spp., we do not believe that this microorganism could have contributed to the problem in this herd. In cows with leptospirosis, usually the 4 quarters are affected (George et al., 2008; Radostits et al., 2007). The bloody milk is usually thick with blood and milk clots are present (George et al., 2008; Radostits et al., 2007). The affected udders are usually flaccid and affected cows commonly experience other clinical signs such as fever, hemoglobinuria, abortion, and decrease in appetite and milk yield (George et al., 2008; Radostits et al., 2007). None of these signs was present in the cows in this study. Moreover, careful environmental investigation and examination of the diet in this herd could not locate any toxic plants and the hematology evaluation has ruled out thrombocytopenia as a possible cause.

Traditional treatments in cows with bloody milk include injection of calcium solutions, parenteral coagulants (Adrenochrome monosemicarbazone, or Tranexamic acid) and intramammary coagulants (Thrombonar) (George et al., 2008; Muhammad et al., 1997; Radostits et al.,

Tab. 3. Mean \pm SD of certain hematology parameters in 15 Holstein dairy cows affected with hemolactia before and after the intravenous injection of $500-\mathrm{ml} 0.37 \%$ formalin solution.

\begin{tabular}{|c|c|c|c|c|}
\hline \multirow[b]{2}{*}{ Parameter } & \multirow[b]{2}{*}{ Normal $(n=10)$} & \multirow[b]{2}{*}{ Control $(n=10)$} & \multicolumn{2}{|c|}{ Treated cows $(n=15)$} \\
\hline & & & $\begin{array}{c}\text { Before } \\
\text { administration }\end{array}$ & $\begin{array}{l}1 \text { week after last } \\
\text { administration }\end{array}$ \\
\hline WBC $\left(\times 10^{3}\right.$ cells $\left./ \mu \mathrm{l}\right)$ & $10 \pm 2.0$ & $9 \pm 1.5$ & $10.3 \pm 2.0$ & $11.5 \pm 2.5$ \\
\hline RBC $\left(\mathrm{x} 10^{6}\right.$ cells $\left./ \mu \mathrm{l}\right)$ & $7.0 \pm 0.5$ & $75.0 \pm 0.5$ & $7.2 \pm 0.7$ & $6.5 \pm 1.3$ \\
\hline $\mathrm{Hb}(\mathrm{g} / \mathrm{dl})$ & $11 \pm 1.3$ & $10 \pm 1.0$ & $11 \pm 1.2$ & $10 \pm 1.0$ \\
\hline PCV\% & $28 \pm 2.5$ & $30 \pm 2.0$ & $34 \pm 4.0$ & $32 \pm 4.0$ \\
\hline $\operatorname{MCV}(\mathrm{fl})$ & $47 \pm 5.0$ & $51 \pm 3.0$ & $47 \pm 4.5$ & $52 \pm 5.0$ \\
\hline $\mathrm{MCH}(\mathrm{pg})$ & $14 \pm 2.0$ & $13 \pm 2.5$ & $14 \pm 1.2$ & $15 \pm 2.5$ \\
\hline $\mathrm{MCHC}(\mathrm{g} / \mathrm{dl})$ & $30 \pm 1.5$ & $31 \pm 1.5$ & $31 \pm 0.1$ & $30 \pm 0.6$ \\
\hline
\end{tabular}
volume, MCHC- mean corpuscular hemoglobin concentration.

Tab. 4. Mean \pm SD of certain serum biochemical analyses parameters in 15 Holstein dairy cows affected with hemolactia before and after the intravenous injection of $500-\mathrm{ml} 0.37 \%$ formalin solution.

\begin{tabular}{|c|c|c|c|c|}
\hline \multirow[b]{2}{*}{ Parameter } & \multirow[b]{2}{*}{ Normal $(n=10)$} & \multirow[b]{2}{*}{ Control $(n=10)$} & \multicolumn{2}{|c|}{ Treated cows $(n=15)$} \\
\hline & & & $\begin{array}{c}\text { Before } \\
\text { administration }\end{array}$ & $\begin{array}{l}1 \text { week after last } \\
\text { administration }\end{array}$ \\
\hline AST (U/L) & $88 \pm 30$ & $98 \pm 15$ & $50 \pm 17$ & $62 \pm 17$ \\
\hline ALT (U/L) & $40 \pm 14$ & $42 \pm 11$ & $30 \pm 10$ & $30 \pm 5.0$ \\
\hline $\operatorname{ALP}(\mathrm{U} / \mathrm{L})$ & $96 \pm 13$ & $110 \pm 19$ & $75 \pm 80$ & $227 \pm 115^{*}$ \\
\hline Total protein $(\mathrm{g} / \mathrm{L})$ & $77 \pm 12$ & $85 \pm 8$ & $85 \pm 14$ & $70 \pm 14$ \\
\hline BUN (mmol/L) & $3.2 \pm 3.0$ & $4.0 \pm 2.0$ & $3.7 \pm 2.5$ & $3.8 \pm 1.8$ \\
\hline Creatinine $(\mu \mathrm{mol} / \mathrm{L})$ & $56 \pm 6.0$ & $66 \pm 3.0$ & $55 \pm 10$ & $60 \pm 5.0$ \\
\hline Calcium (mmol/L) & $3.0 \pm 0.7$ & $3.5 \pm 0.5$ & $2.8 \pm 0.5$ & $2.9 \pm 0.5$ \\
\hline Sodium (mmol/L) & $140 \pm 10$ & $141 \pm 2$ & $141 \pm 4.5$ & $144 \pm 1.4$ \\
\hline Chloride (mmol/L) & $103 \pm 5.0$ & $102 \pm 5.0$ & $101 \pm 0.90$ & $104 \pm 2.5$ \\
\hline Potassium (mmol/L) & $5.5 \pm 5.0$ & $4.9 \pm 5.0$ & $6.0 \pm 1.0$ & $6.8 \pm 1.2$ \\
\hline
\end{tabular}

AST- aspartate aminotransferase, ALT- alanine aminotransferase, ALP- alkaline phosphatase, BUN- blood urea nitrogen. 
2007). However, some of these treatments are not always available, expensive and most importantly lack the clinical and experimental data to support their safety and efficacy. Therefore, an innovative, effective and yet cheap and safe alternative treatment is still warranted.

Formalin has been widely used in laboratories as a preservative, tissue fixative, disinfectant and embalming agent for many years (EFSA, 2004). Recent medical reports in dogs, horses and human medicine have indicated a beneficial effect of using formalin to control hemorrhage. It was suggested that formalin enhances primary hemostasis through enhancing endothelial or platelet activation mechanisms (Choong et al., 2000; Mathai et al., 1995; Henrikson et al., 2004; Kang et al., 2003; Lee et al., 2007; Mohamed et al., 2012). In this study, platelets numbers were significantly increased after the administration of the drug while only APTT values were significantly decreased in treated cows.

In this study, almost $81 \%$ of affected quarters were completely cured after 2 to 7 once per day injections of formalin. Although in human beings with urinary bladder and rectal bleeding, formalin has been used by topical or intralesional application, the use of formalin intravenously in cattle presents quick and easy way to administer in field situations. The success rate of using formalin for intractable hemorrhage in human beings is reportedly around $70-92 \%$ (Choong et al., 2000) which is similar to the results reported here $(81 \%)$.
Formaldehyde is considered toxic and carcinogenic naturally occurring substance (EFSA, 2004). Local toxic effects of formalin have been reported in some human patients including contracted urinary bladder, urinary incontinence, ureteral stenosis and obstruction, hydroureteronephrosis, renal damage and rupture of the bladder (Choong et al., 2000). In this study, we used intravenous formalin injection in a very low concentration based on previous studies in horses (Taylor et al., 2000). Larger volumes and higher concentrations of formalin in horses have been reported to cause mild to moderate toxic signs (Taylor et al., 2000). In this study, there were no abnormal clinical signs associated with the intravenous injection of $500-\mathrm{ml}$ of $0.37 \%$ solution of formaldehyde. In addition, the hematology and serum biochemical analyses revealed no significant changes that may indicate systemic toxicity.

Although formalin residues in milk were not measured in this study, endogenous background formalin levels in meat and milk and formalin levels in cows' milk, blood and tissues fed formalin-treated whey were determined previously and found below the determined toxic levels in human beings (Buckley et al., 1988; EFSA, 2004). Nevertheless, future research is warranted to determine acceptable levels of formalin in milk and meat of dairy cows after intravenous administration of this drug.

Tab. 5. Mean \pm SD of platelets numbers, fibrinogen concentration, and certain clotting factors in 15 Holstein dairy cows affected with hemolactia before and after the intravenous injection of $500-\mathrm{ml} 0.37 \%$ formalin solution.

\begin{tabular}{ccccc}
\hline Parameter & Normal cows & Control cows & \multicolumn{2}{c}{ Treated cows (n=15) } \\
\cline { 4 - 5 } & $(\mathrm{n}=10)$ & $350 \pm 110)$ & $\begin{array}{c}\text { Before } \\
\text { administration }\end{array}$ & $\begin{array}{c}\text { 1 week after last } \\
\text { administration }\end{array}$ \\
\hline Platelet $\left(\mathrm{x} 10^{3}\right.$ cells/ $\left.\mu \mathrm{L}\right)$ & $370 \pm 130$ & $30 \pm 0.5$ & $27 \pm 2.0$ & $27 \pm 4.0$ \\
\hline PT (seconds) & $29 \pm 0.5$ & $55 \pm 7.0$ & $60 \pm 10$ & $47 \pm 10^{*}$ \\
\hline APTT (seconds) & $56 \pm 7.0$ & $28 \pm 3.0$ & $27 \pm 5$ & $30 \pm 6.0$ \\
\hline TT (seconds) & $29 \pm 3.0$ & $<0.5$ & $<0.5$ & $<0.5$ \\
\hline D-dimer (ng/ml) & $<0.5$ & $550 \pm 200$ & $750 \pm 150$ & $675 \pm 250$ \\
\hline Fibrinogen $(\mathrm{mg} / \mathrm{dL})$ & $600 \pm 200$ & & &
\end{tabular}

PT- prothrombin time, APTT- activated partial thromboplastin time, TT- thrombin time. 


\section{CONCLUSION}

Results of this study prove an effective and safe, widely available and cheap treatment for dairy cows affected with bloody milk not associated with physiologic udder edema in one or more quarters. This innovative treatment is once per day intravenous administration of $500-\mathrm{ml}$ of $0.37 \%$ formaldehyde solution with or without intravenous calcium solutions or intramuscular vitamin $\mathrm{K}$ injections.

\section{REFERENCES}

1. Ayaz MM (1999). Hematogalactia in goats and buffalo Pakistan Vet J 19:161-162.

2. Buckley KE, Fisher LJ, Mackay VG (1988). Levels of formaldehy de in milk, blood, and tissues of dairy cows and calves consuming formalin-treated whey. J Agric Food Chem 36: 1146-1150.

3. Choong SKS, Walkden M, Kirby R (2000). The management of intractable haematuria. BJU International 86:951-959.

4. George LW, Divers TJ, Ducharme N, Frank L (2008). Diseases of the teats and udder. In: Divers TJ, Peek SF (Eds). Rebhun's Diseases of Dairy Cattle, 2 nd ed, Saunders Elsevier , St Louis, Missouri, 327- 394.

5. Eddy RG, Clark SJ (1982). Blood in milk. Vet Rec 110:482.

6. European Food Safety Authority (2004). Endogenous formaldehyde turnover in humans compared with exogenous contribution from food sources. EFSAJ $12: 3550$

7. Henrikson TD, Moore L, Biller DS, Schermerhorn T (2004). Intravesical instillation of dilute formalin for the treatment of severe hemorrhagic emphysematous cystitis in a diabetic dog. J Am Anim Hosp Assoc 40:64-68.
8. Jones W (1998). IV formalin to control hemorrhage. J Equine Vet Sci 18:581.

9. Kang JC, Chao P, Wu C, Lee C, Yeh C, Hsiao C, Jao S (2003). Endoscopic therapy with topic formalin for treatment of refractory lower gastrointestinal bleeding. J Med Sci 23:161-164.

10. Lee S, Park Y, Sohn SK (2007). Formalin application for the treatment of radiation-induced hemorrhagic proctitis. Yonsei Med J 48:97-100.

11. Manikandan R, Kumar S, Dorairajan LN (2010). Hemorrhagic cystitis: A challenge to the urologist. Indian J Urol 26:159-166.

12. Mathai V, Seow-Choen F (1995). Endoluminal formalin therapy for haemorrhagic radiation proctitis. Br J Surg 95:82,190.

13. Mohamed A, Mohammed R, Hicham E (2012). The Use of Intravesical formalin for hemorrhagic cystitis: Our experience. Urology 3:3412.

14. Muhammad G, Zia T, Athar M, Khan MZ (1997). Haemogalactia (blood in milk) in a buffalo. Pakistan Vet J 17:102-103.

15. Oliver SP, Gonzales RN, Hogan JS, Jayarao BM, Owens WE (2004). Microbiological procedures for the diagnosis of bovine udder infection. $4^{\text {th }}$ ed, Madison, WI, National Mastitis Council Inc.

16. Radostits OM, Gay CC, Hinchcliff KW, Constable PD (2007). Diseases of the mammary glands. In: Veterinary Medicine. 10th ed, Saunders Elsevier, Philadelphia, Pennsylvania, 673-762.

17. Taylor EL, Sellon DC, Wardrop KJ, Hines MT, Kingston JK (2000). Effects of intravenous administration of formaldehyde on platelet and coagulation variables in healthy horses. Am J Vet Res 61: 1191-1196. 